\title{
The Difference of Mathematics Learning Achievement between Ipad For Learning Multimedia Learning and Conventional Learning Media in Junior High School Students
}

\author{
Tsurayya Syarif Zain ${ }^{1} \mathcal{E}$ Saifuddin Azwar ${ }^{2}$ \\ Fakultas Psikologi Universitas Gadjah Mada
}

\begin{abstract}
This research included gender as moderator as well as the intelligence and motivation of learning as the covariance of learning achievement. The research design was causal-comparative by comparing mathematics learning achievement between learning with iPad and conventional media. The overall research's subjects were 128 junior high school students. Data analysis was done using analysis of covariance (ANCOVA). The result showed that there was differences in learning achievement between multimedia learning iPad for Learning and conventional learning media $(F=48.698, p<0.05)$. Students who used iPad media had an average mathematics learning achievement higher than a student in conventional learning media. In this research, the interaction between genders and learning media on mathematics learning achievement was proven to be low $(F=0.318, p>0.05)$.
\end{abstract}

Keywords: iPad for Learning; digital learning; mathematics academic achievement

Mathematics education in Indonesia, based on the research conducted by Program for International Student Assesment (PISA), it stated that Indonesian children's ability in mathematics and science subjects is still very low. It was also mentioned by the Federation of Indonesian Teacher Union (FSGI), which shows that the quality of education in Indonesia still ranked 12 and the lowest in Asia (CIU, 2013). In addition, the data of Pisa showed that mathematics and science ability in junior high school students in Indonesia in 2015 ranked 69 of 76 countries around the world (Coughlan, 2015). Some of PISA's research findings also showed that female students have a lower mathematical ability level than male students (Buckley, 2016). A study conducted by Geary, Saults, Liu, and ${ }^{1}$ Korespondensi dapat dilakukan melalui tsurayyasyarif@gmail.com

22Atau melalui sfazwar@ugm.ac.id
Geary, Saults, Liu, \& Hoard (2000) showed that male students have a higher score of mathematical ability than female students.

Anderman and Mueller (2010) revealed that the process of someone to gain achievement is related to internal and external factors. Some internal factors that affect the learning achievement are among others, intelligence and motivation. Intelligence is an important component in predicting learning achievement. Some researchers showed that intelligence is one of determining factors of learning achievement which has a great influence, both in students' failure and success. Students with high intelligence generally find it easier to understand the problems compared to students who have low intelligent (Gras, Bordoy, Juste, Corbalan, 2010). 
In addition to intelligence, motivation is also a predictor and an important component in learning achievement. Rao (2013) mentioned that positive and significant learning achievement is very closely related to the students' motivation. A study conducted by Elias, Mustafa, Roslan, and Noah (2011) showed that the variable in the motivation is a strong predictor in determining students' academic scores which simultaneously contributes as much as $25 \%$ in learning performance.

In addition to the internal factors, an external factor that affects learning achievement is learning facilities such as learning media (Suryabrata, 2012). Nowadays, digital technology media is a new innovation of education media used in the learning system. Digital technology such as gadget is a combination of mobile phone and PDA (personal digital assistant) which functionally has multimedia applications including Internet access. One of the gadgets used as a major media in school learning is an iPad. iPad for learning is digital-based tablet computing learning media integrated with learning system at school (Clark \& Lucin, 2013). The previous study found that the use of iPad can support students in understanding as well as gaining better mathematics learning outcome (Martinez, 2017). Overall, the use of digital technology in class can improve students' academic achievements. The students' achievements applying digital class tend to be higher than the students' achievements using conventional media (Chen et al., 2013; López, 2010; Ozerbas \& Erdogan, 2016).

Some schools in Southeast Asia have made $i P a d$ as integrative and systemized learning media with the school. In Indonesia, one of the schools becoming the official pilot project of iPad for learning and registered as part of the Apple South Asia is Al-Azhar Islamic Junior High School in Palembang.
Based on the interview at Al-Azhar Islamic Junior High School in Palembang, it was found that iPad facilitates the application needed in the learning processes such as GeoGebra and geometric 3D applications to mathematics subject material. By using $i-$ tunes $U$ application, students can do and send the task to teachers without constrained time and place. Teachers can monitor students who do not do tasks and can communicate directly with their parents. In order to avoid the use of the iPad out of the learning context, the school has a controller system viz. Mobile Device Manager (MDM). This system helps to control all kinds of applications that are not related to the learning context in order not to be accessed by students (the results of an interview with A.F, iPad Classroom coordinator on January $20^{\text {th }}, 2017$ ).

However, in 3-year implementation, this program had never been evaluated in the application of iPad for learning at AlAzhar Islamic Junior High School in Palembang. The evaluation was expected to determine the effect of the iPad for learning for school learning and keep its quality and development towards a better and sustainable program. To find out its impact in students' learning achievements in mathematics subject, the researcher intended to compare Al-Azhar Islamic Junior High School which uses iPad for learning to another equivalent Al-Azhar Islamic Junior High School which does not use iPad for learning for the learning process. Based on the description above, the researcher was interested to hold research related to the difference of mathematics learning achievement between iPad for learning multimedia learning and conventional learning media of students at Al-Azhar Islamic Junior High School. The hypothesis in this study is there are differences of mathematics learning achievement between students using iPad for learning multimedia learning and conventional learning in which 
students' mathematics learning achievements using iPad for learning multimedia learning is higher than students' mathematics learning achievements which use conventional learning media.

\section{Method}

Subjects in this study were ninth-grade students of Al-Azhar Islamic Junior High School which consisted of the students of AlAzhar Islamic Junior High School who applied iPad for learning and the students of another equivalent Al-Azhar Islamic Junior High School who applied non-iPad (conventional) learning media aged 13-15. The overall research's subjects were 128 students consisting of 32 male students and 32 female students from both iPad user group and non-iPad user (conventional) group. In this study, a score of mathematics learning achievement was average score of previous year's mathematics semester final exam (UAS) i.e. when the students were in the second semester of seventh and eighth grade. The mathematics achievement data were obtained from the document of mathematics test results in the form of raw score.

Student's average score $=$

$x=$

-sum of semester final exam scores in 7 th and 8th grade 2

In this study, gender was a moderator variable while intelligence and motivation were used as covariable to deepen the analysis of the research. The intelligence score was obtained from the scale 3 CFIT intelligence test, while the learning motivation score was obtained from learning motivation score compiled by Kristiyani (2016) which was tested with CVI (content validity index) statistical calculations of 0.90 with the reliability of 0.722 . In this study, the research data were analyzed with ANCOVA or 2-line covariant analysis, in which mathematics learning achievement was the independent variable, learning media was the dependent variable, gender was moderator variable, and intelligence and learning motivation were used as a covariable.

\section{Results}

This research tested if there was a difference between students using iPad for learning multimedia learning and conventional learning. By including intelligence and learning motivation as covariable in this study, then both covariables theoretically and analytically should show a correlation with learning achievement prior to know the difference between the two tested groups. This study proved that the intelligence and learning motivation correlate with mathematics learning achievement, in which the intelligence variable earned $F=4.597$ with the significance of $0.03(p<0.05)$. With the partial value of 0.036 , it could be assumed that the contribution of intelligence to mathematics learning achievement is $3.6 \%$.

It meant no significant correlation between intelligence and learning media to the students' mathematics learning achievement scores. While motivation variable earns $F=7.952$ with the significance of $0.000(p<0.01)$. With the partial value of 0.061 , it can be assumed that the contribution of learning motivation to mathematics learning achievements is $6.1 \%$. It means no very significant correlation between the learning motivation and learning media to the students' mathematics learning achievement score.

\section{Discussion}

The previous research supports the findings in this research related to intelligence. In the 
education world, intelligence is an important component to know the process and learning outcomes for the intelligence level is diverse among the students (Calvin, Deary, Roberts, \& Leckbenky., 2012). Intelligence is related to the learning performance because it involves problem-solving skill and the understanding of taught material (Dunlosky \& Metcalfe, 2008). Gras et al. (2010) found that students with a high intelligence level tend to be easier to analyze a problem and to find the solution. In addition to intelligence, learning motivation is also an important component in the learning process for motivation has a function to encourage and to direct the students to initiate learning activities. Student's motivation at school is triggered by cognitive perspective and emphasis to find the most important process related to students' achievements (Anderman \& Anderman, 2010; Santrock, 2014). A study conducted by Elias et al. (2011) showed that the variable in the motivation is a strong predictor in determining students' academic score simultaneously contributing as much as $25 \%$ in learning achievement.

To answer the hypothesis "there are differences in students' mathematics learning achievement scores among students who use iPad for learning media learning and students who use conventional media learning", analysis result with 2-line covariant analysis indicates that learning media variable earns $F=48.698$ with the significance of $0.000 \quad(p<0.05)$. Students' mathematics learning achievement scores using iPad have a mean of 73.703 with the standard deviation of 12.264, while the student's achievements using conventional media have a mean of 55.617 with the standard deviation of 12.001 . It can be concluded that there is a very significant difference in mathematics learning achievement score between the group using iPad media and the group using conventional media in the learning process.
It can be assumed that the hypothesis in this study is proven. By controlling the intelligence and learning motivation, there is a difference in students' mathematics learning achievement scores between the students using iPad for learning as learning media and students using conventional learning media. In average, students who use iPad for learning as learning media have higher mathematics learning achievement scores than students who use conventional learning media learning.

The previous research supported the hypothesis test result in this study. Overall, the use of digital technology in class can improve the students' academic achievements. The student's achievements in applying digital class tend to be higher than the student's achievement using conventional media (Chen et al., 2013; López, 2010; Ozerbas \& Erdogan, 2016). Through the digital-based learning activities, the students can learn attractively, improve student's motivation, resulting in a higher level of success. In addition, another reason is a website that is used in the digital class allows students to access the class' document, to review their material, and also to provide communication among class partners. Digital technology that is well integrated with the curriculum generally is able to give a positive effect on the students' performance and the level of academic success (López, 2010; Guven, \& Sülün, 2012; Chen et al., 2013).

Based on the interaction test results between learning media and gender, the results shows value $F=0.318$ with the significance of $0.57(\mathrm{P}>0.05)$. It means that there is no interaction between the learning media and gender on the mathematics learning achievement. However, the result shows that the mathematics learning achievement of female students tend to be higher than male students. It is evidenced by the different mean in mathematics learning 
achievement scores among female students and male students. Male students who use iPad have learning achievement mean of 72.937 with the standard deviation of 12.658. While mathematics learning achievement mean of female students who use media iPad is 74.468 with the standard deviation of 12.010. Male students who use conventional media have learning achievement mean of 52.328 with the standard deviation of 13.417 . While learning achievement means of female students who use conventional media is 58.906 with the standard deviation of 9.505. Therefore, although female and male students have a different mean of achievement learning score, statistically there is no difference in mathematics learning achievement scores related to the gender in any groups. It is shown on the results of the interaction between gender and learning media at the insignificant mathematics learning achievement.

Some previous researches prove that the mathematics learning achievement of female students tends to be higher than male students. Although male students have much higher average score in the arithmetic calculation, reasoning arithmetic, and spatial cognition measurement than female students (Geary et al., 2000), but female students tend to have the higher mathematics achievement and motivation than male students. Generally female students' performances tend to be better than male students' because female students' motivation is higher than male students' (Campbell, 2005; Schoon \& Polek, 2011; Guo, Marsh, Parker, Morin, \& Yeung, 2015). Although male students are more interested in the use of digital learning (Gee, 2007., \& Unlusoy, de Haan, Leseman, \& van Kruistum, 2010), but some researches found both female students and male students have the same interest in digital-based learning (Agosto, 2004., \& Vogel. 2006).
To obtain deeper information of the perception of the students in the application of $i$ Pad for learning in the learning process at Al-Azhar Islamic Junior High School in Palembang, researchers included questionnaire attaching choice questions and essay distributed and filled by all students online. Based on given questionnaire, the results showed that $72 \%$ of students gave response to high category, $18 \%$ of students responded to moderate category, and $10 \%$ of students responded to low category. It means that most of the students respond positively to the use of an iPad at school. Some reasons underlying positive response of students to the use $i \mathrm{Pad}$, among others is the ease and flexibility in tasks and information access, independent learning, and paperless so the students do not need to bring many books. Most of the students who responded to the moderate and low category in the application of $i \mathrm{Pad}$ gave reasons that they complained about their eye health so sometimes students experienced difficulty to concentrate.

The advantages of the application of $i P a d$ for learning according to the student are learning systematically, integratedly, easily, and efficiently. The result of the questionnaire response shows that $80 \%$ of students find it helpful by the use of iTunes $U$ and Safari in the learning process. iTunes $U$ application is a platform that serves to integrate digital technology in the learning process. By using iTunes $U$, the students can record and save the material neatly, give highlights on iBook as a reference to study, share learning information thoroughly to the teacher and all students in the class, and submit the daily tasks to teachers, and get quick and flexible feedback (quoted from www.macworld.co.uk).

Some of these advantages were apparently supported by the findings of previous studies. Research by Henderson and Yeow (2012) said that the collaborative 
learning conducted by the teacher through $i \mathrm{Pad}$ allows students to discuss easily in the context of the learning of formal to informal, personal to social, and can control what they learn. In addition, the $i P a d$ effectively is an easy way to connect someone in spite of the distance, location, and different places. Teachers can easily send the performance results of the students to parents as well as provide suggestion to parents to involve in learning with students at home (Heinrich, 2012). A study conducted by Swan, Hooft, Kratcoski, and Schenker (2007) found that the impact of the use of digital classroom in the learning process, among others is increasing motivation and students' involvement compared to the regular class that does not use integrated technology system. Overall, the iPad for learning supports collaborative learning, personalized learning experienced, deep learning, and distributive and connected learning (Clark \& luckin, 2013).

Although the iPad for learning contributed positively to the students, the use of this media at school also raises some problems which limit the use of the iPad at school. Based on the questionnaire, it mentioned that eye health problems were experienced by the students due to the use of $i$ Pad at school continuously. The students were still expected to get the learning by using books as the media. The students considered the use of books and written media to train their writing skills and not to experience eye health problem. It was also proven that $41 \%$ of students hope that the teacher taught without $i \mathrm{Pad}$ and as much as $59 \%$ of students were more comfortable if the teacher taught by using $i \mathrm{Pad}$ as the media. Unfavorable WiFi network was also the obstacle in the effective learning process in digital class. This might affect iPad effectiveness in collecting duties and receiving feedback directly from the teacher.

\section{Conclusions}

This study concluded that there was difference in mathematics learning achievement between students who used iPad as learning media and students who used conventional media in the learning process. Students who used iPad for learning as learning media, in the average, have higher mathematics learning achievement than students who used conventional media learning. This study also proved that there was no interaction between gender and learning media in mathematics learning achievement. However, it was proven that mathematics learning achievement of female students tend to be higher than male students.

Most of the students responded positively to the application of the $i \mathrm{Pad}$ for learning at school. The advantages of the application of $i \mathrm{Pad}$ for learning according to the students were the ease and flexibility in tasks and information access, independent learning, and paperless so students did not need to bring many books. Based on the questionnaire, it mentioned that eye health problems were experienced by students due to the use of $i \mathrm{Pad}$ at school continuously. The students were also expected to get the learning by using books as the media. Students considered the use of books and written media to train their writing skills and not to experience an eye health problem. Unfavorable WiFi network was also an obstacle in the effective learning process in digital class. This might affect iPad effectiveness in collecting duties and receiving feedback directly from the teacher.

\section{Recomendation}

Suggestion for the school is a relation with the high mathematics learning achievement level on the subjects, the researcher advises the school to be able to maintain and improve the achievement. However, the 
subjects need the resting time to be away from the use of iPad impacting eye health and concentration strength.

The future researchers who are interested in the same theme are expected to examine the other factors that affect the learning achievement, especially at digital school, given that the technology is growing and innovating so that it is noteworthy especially in the education field.

This study compared two schools in different cities so that they can be advised to future researchers to compare the two groups in the same city and school. In addition, by looking at students' intelligence scores in the conventional group which is higher than the iPad group, it is suggested to the future research in order to investigate the mathematics learning achievement in the group that has a high intelligence score when it is given $i \mathrm{Pad}$ as learning media.

It is assumed by the researcher that the possibility of low mathematics achievement score in the group which has a high intelligence among others is because of the boredom of the students in the group with the used media so the students will be more interested in more innovative and interesting media. In this study, the research's subjects were students at Junior High School level. Given the fact that the digital school now penetrates the elementary school level, it is advised to the future researchers to particularly expand the research's subjects in children.

\section{References}

Agosto, D. E. (2004). Girls and gaming: A summary of the research with implications for practice. Teacher
Librarian, 31(3), 8-14. doi: 10.1162/pres.15.3.309

Anderman, E. M., \& Mueller, C. (2010). Middle school transitions and adolescent development; Disentangling psychological, social, and biological effects. In J. Meece \& Eccles (Ed.), Handbook of research on schools, schooling and human development. New York: Psychology Press

Buckley, S. (2016). Gender and sex differences in student participation, achievement, and engagement in mathematics. Camberwell: Australian Council for Educational Research

Calvin, C. M., Deary, I. J., Fenton, C., Roberts, B. A., Der G., Leckenby, N. (2012). Intelligence in youth and allcause-mortality: Systematic review with meta-analysis. International Journal of Epidemiology, 40(3), 626644. doi: $10.1093 /$ dyq190

Campbell, J. I. D. (2005). Handbook of mathematical cognition. New York and Hove : Psychology Press

Chen, G. D., Nurkhamid, Wang, C. Y., Yang, S. H., Lue, W. Y., \& Chang, C. K. (2013). Digital learning playground: Supporting authentic learning experiences in the classroom. Interactive Learning Environments, 21(2), 172-183. doi: 10.1080/ $\underline{10494820.705856}$

Ciu, F. S. (2013, Januari 8). Nilai Matematika siswa RI 10 besar terendah di dunia. Berita Online Okezone. Retrieved from http://www.okezone.com

Clark, W., \& Lucin, R. (2013). What the research says: iPad in the classroom. Journal of Leading Education and Social Research. University of London. Retrieved from https://digitalteachingandlearning.f iles.wordpress.com/2013/03/ipadsin-the-classroom-report-lkl.pdf 
Coughlan, S. (2015, Mei 13). Asia peringkat tertinggi sekolah global, Indonesia nomor 69. Retrieved from: http://www.bbbc.com

Dunlosky, J., \& Metcalfe, J. (2008). Metacognition. CA: Sage

Elias, H., Mustafa, S. M. S., Roslan, S., \& Noah, R. S. M. (2011). Motivational predictors of academic performance in end year examination. ProcediaSocial and Behavioral Science, 29, 11791188. doi: 10.1016/j.sbspro. $\underline{2010.03 .116}$

Geary, D. C., Saults, S. J., Liu. F., \& Hoard, M. K. (2000). Sex differences in spatial cognition, computational fluency, and arithmetical reasoning. Journal of Experimental Child Psychology, 77, 337-353. doi: 10.1006/jecp.2000.2594

Gee, J. P. (2007). In what video games have to teach us about learning and literacy. Basingstoke: Palgrave Macmillan

Gras, R. M., Burdoy, M., Juste, G., \& Corbalan, J. C. (2010). Creativity, intellectual abilities and response styles: Implications for academic performance in the secondary school. Anales de Psicologia, 26(2), 212-219.

Guo, J., Marsh H. W., Parker, P. D, Morin, A. J. S, Yeung, A. S. (2015). Expectancyvalue in mathematics, gender and socioeconomic background as predictors of achievement and aspirations: A multi-cohort study. Learning and Individual Differences, 37, 161-168. doi: 10.1016/j.lindif. $\underline{2015.01 .008}$

Guven, G., \& Sulun, Y. (2012). The effects of computer-enhanced teaching on academic achievement in 8th grade science and technology course and students attitude towards the course. Journal of Turkish Science Education, 9(1), 68-79. doi: 10.5539/ ies.v10n9p152
Heinrich, P. (2012). The iPad as a tool for education. NAACE and gine consulting, 27(2), 834-844. doi: 10.1016/j.chb.11.008

Henderson, S., \& Yeow, J. (2012). 'iPad in Education - A case study of iPad adoption and use in a primary school'. HICSS '12 Proceedings of the 2012 45th Hawaii International Conference on System Sciences, 78-87. doi: 10.1109/HICSS.2012.390

Kristiyani, T. (2016). Dari trilogi ke ekologi: Dinamika sumbangan motivasi belajar, metakognisi, dan strategi kognitif bagi prestasi belajar matematika siswa IX SMP. Disertasion unpublished. Psikologi Universitas Gadjah Mada.

López, O. S. (2010). The digital learning classroom: Improving English language learners' academic success in mathematics and reading using interactive whiteboard technology. Computers \& Education Journal, 54 (4), 901-915. doi: 10.1016/j.compedu. 2009.09.019

Martinez, A. R. (2017). The effects of using GeoGebra on student achievement in secondary mathematics. Thesis of Califormia State University, Monterey Bay. Retrieved from https: //digitalcommons.csumb.edu/caps thes all/137/

Ozerbas, M. A., \& Erdogan, B. H. (2016). The effect of the digital classroom on academic success and online technologies self-efficacy. Educational Technology \& Society, 19(4), 203-212. doi: $10.1007 / \mathrm{s} 11528-$ 015-0860-Z

Rao, M. S. (2003). Achievement motivation and achievement in Mathematics. New Delhi: Discovery Publishing House

Santrock, J. W. (2014). Educational psychology, 5th ed. Jakarta: Salemba Humanika.

Schoon, I., \& Polek, E. (2011). Teenage career aspirations and adult career attainment: The role of gender, 
social background and general cognitive ability. International Journal of Behavioral Development, 35(3), 210-217. doi: 10.1177/ $\underline{0165025411398183}$

Suryabrata, S. (2012). Psikologi pendidikan. Jakarta: Fajar Interpratama Offset.

Swan, K., Hooft, M., V., Kratcoski, A. \& Schenker, J. (2007). Ubiquitous computing and changing possibilities: Representations, conceptualizations and uses of knowledge. Journal of Educational Computing Research, 36(4) 481-515. doi: 10.2190/B577-7162-2X11-17N5

Unlusoy, A., de Haan, M., Leseman, P. M., \& van Kruistum, C. (2010). Gender differences in adolescents' out-ofschool literacy practices: a multifaceted approach. Computers $\mathcal{E}$ Education, 55(2), 742-751 